\title{
Webinar Bagi Mahasiswa Baru 2021 "Sejarah dan Pemikiran H.O.S. Cokroaminoto"
}

\author{
Heri Kurnia \\ Program Studi Pendidikan Pancasila dan Kewarganegaraan, Fakultas Keguruan dan Ilmu Pendidikan, \\ Universitas Cokroaminoto Yogyakarta, Indonesia \\ Email: herikurnia312@gmail.com
}

\begin{abstract}
This Community Service, is carried out virtually in the form of online or webinars. This activity was organized by the Campus Academic Introduction committee, Cokroaminoto University of Yogyakarta in 2021. This webinar is a routine activity held every year, to introduce a campus environment for new students every year. This activity raised the theme "Historyand Thought of Cokroaminoto", which was carried out using a zoom platform. The purpose of this webinars to get to know more closely the famous figure as well as the nation's teacher, H.O.S. Cokroaminoto, which gave the idea of Indonesia should be independent since 1912. Cokroaminoto helped raise the first national movement organization in Indonesia, the Islamic Trading Company which was established in 1905 with the founding figure H. Samanhudi. Cokroaminoto holds the title of teacher of the nation, because he has 3 famous students: Sukarno, Musso and Kartosuwiryo, all three of whom have different ideologies: Nationalists, Communists and Religious, as well as his three disciples also managed to color the journey of this nation, even more so during the old order. In the implementation of this webinar, it appears that the participation, enthusiasm and spirit of the participants, so that this webinar activity can be carried out properly and smoothly.
\end{abstract}

Keywords: Webinar, history of Cokroaminoto, Cokroaminoto thinking, Cokroaminoto University of Yogyakarta.

\begin{abstract}
Abstrak
Pengabdian Kepada Masyarakat ini, dilaksanakan secara virtual dalam bentuk daring atau webinar. Kegiatan ini diselenggarakan oleh panitia Pengenalan Akademik Kampus (PAK) Universitas Cokroaminoto Yogyakarta Tahun 2021. Kegiatan ini merupakan kegiatan rutin yang diselenggarakan setiap tahunnya, guna untuk mengenalkan lingkungan kampus bagi mahasiswa baru setiap tahunnya. Kegiatan ini mengangkat tema "Sejarah dan Pemikiran Cokroaminoto", yang dilaksanakan dengan menggunakan platform zoom. Tujuan kegiatan ini untuk mengenal lebih dekat tokoh ternama sekaligus guru bangsa yaitu H.O.S. Cokroaminoto, yang memberikan gagasan Indonesia harus merdeka sejak tahun 1912. Cokroaminoto ikut membesarkan organisasi pergerakan nasional pertama di Indonesia yaitu Syarikat Dagang Islam (SDI) yang berdiri sejak tahun 1905 dengan tokoh pendiri H. Samanhudi. Cokroaminoto menyandang gelar guru bangsa, karena dia memiliki 3 murid ternama: Sukarno, Musso dan Kartosuwiryo yang ketiganya memiliki ideologi berbeda-beda: Nasionalis, Komunis dan Agamis, serta ketiga muridnya pun berhasil mewarnai perjalanan bangsa ini, terlebih lagi pada masa orde lama. Dalam pelaksanaan webinar ini, tampak sekali partisipasi, antusias dan semangat dari para peserta, sehingga kegiatan webinar ini dapat terlaksana dengan baik dan lancar.
\end{abstract}

Kata Kunci: Webinar, sejarah Cokroaminoto, pemikiran Cokroaminoto, Universitas Cokroaminoto Yogyakarta

\section{A. PENDAHULUAN}

Webinar merupakan istilah yang digunakan dalam dunia kajian khususnya dalam kegiatan seminar yang dilakukan secara daring (online), biasanya menggunakan situs web atau aplikasi tertentu berbasis internet (Compen et al., 2021). Menurut Brumfiel et al., (2021) Kegiatan semacam ini memungkinkan bagi pembicara atau pengisi materi membagikan informasi melalui jarak jauh, tepatnya melalui internet maupun media elektronik lainnya. Seperti yang kita ketahui bersama semenjak adanya pandemik covid-19 di Dunia khususnya di Indonesia, yang berawal sekitar bulan Februari 2020 yang lalu (Gegenfurtner et al., 2020). Maka, secara serentak dan bahkan mendunia semua kegiatan 
dilakukan secara virtual dalam jaringan (daring) atau lebih sering kita sebut dengan istilah online, termasuk didalamnya kegiatan di sekolah bahkan sampai perguruan tinggipun dilaksanakna secara online (Hennus \& Dam, 2021). Demikian juga halnya dengan kegiatan Pengenalan Akademik Kampus (PAK) di kampus Universitas Cokroaminoto Yogyakarta yang dilakukan secara daring. Pemateri menyadari memberikan materi secara virtual bukanlah hal mudah untuk diterima dan diserap oleh peserta webinar ini, namun pemateri berusaha memberikan yang terbaik bagi peserta PAK tahun 2021 ini.

Selanjutnya, seperti yang sudah kita ketahui bersama masyarakat Indonesia tentunya sudah mengetahi sebuah ungkapan yang disampaikan oleh Bung Karno (Ir. Soekarno) presiden Republik Indonesia yang pertaman yakni sebuah akronim yaitu "JAS MERAH" artinya jangan sekali-kali melupakan sejarah (Wijaya, 2019). Sejarah yang selama ini diterima oleh bangsa Indonesia harus mulai kita benahi dan kita luruskan secara perlahanlahan dan mendalam, seperti contoh: organisasi pergerakan nasional pertama di Indonesia pasti $90 \%$ menjawab adalah Budi Utomo (BU), jawaban tersebut tidaklah salah melainkan harus kita luruskan bersama. Organisasi BU berdiri pada tahun 1908, sedangkan ada sebuah organisasi 3 tahun lebih dulu dari padanya, yaitu organisasi dengan nama Syarikat Dagang Islam (SDI) yang sekarang berganti nama menjadi Syarikat Islam. Berdasarkan pendapat dari (Ahdar et al., 2021) maka, perlu pemateri sampaikan, bahwa organisasi pergerakan nasional pertama di Indonesia adalah SDI karena organisasi tersebut berdiri pada tahun 1905, yang diprakarsai oleh H. Samanhudi di Laweyan, Surakarta sekitar 116 tahun yang lalu.

Sejarah mencatat Pada tanggal 16 Oktober 1905 atas prakarsa H. Samanhudi di Surakarta didirikan kumpulan Syarikat Dagang Islam (SDI) karena kaum pedagang di Surakarta merasa terdesak oleh pedagang-pedangan Cina (pedagang baru yang mempunyai perkumpulan sendiri) (Bone \& Cokroaminoto, n.d.). Dengan mengadakan perkumpulan diharapkan dapat besaing dengan pedagang-pedagang Cina yang ada setempat, $\mathrm{H}$. Samanhudi mengumpulkan para pedagang Islam yang ada untuk bersatu menyusun kekuatan menghadapi orang-orang Cina (Fajar, 2021). Jenis Organisasi ini adalah organisasi Islam, dalam istilah lain sering disebut dengan Organisasi Pengkaderan dan Perjuangan. Tujuan awal dibentuknya SDI ialah untuk menghimpun para pedagang pribumi Muslim (khususnya pedagang batik) supaya mampu bersaing dengan pedagang-pedagang besar Tionghoa atau Cina (Fajar, 2021). Pada masa itu, pedagang-pedagang keturunan Tionghoa, sudah lebih maju usahanya dan memiliki hak dan status yang lebih tinggi dari pada penduduk Hindia
Belanda lainnya. Kebijakan yang sengaja diciptakan oleh pemerintah Hindia-Belanda. Kemudian menimbulkan perubahan sosial karena timbulnya kesadaran diantara kaum pribumi yang biasa disebut sebagai Inlanders. Menurut Ahdar et al., (2021) Syarikat Dagang Islam (SDI) juga merupakan organisasi ekonomi yang berdasarkan pada agama Islam dan perekonomian rakyat sebagai dasar penggeraknya. Selanjutnya, menurut Fajar, (2021) di bawah pimpinan $\mathrm{H}$. Samanhudi, perkumpulan ini berkembang pesat hingga menjadi perkumpulan yang berpengaruh pada saat itu. SDI juga tidak membatasi keanggotaannya, dalam artian tidak hanya untuk masyarakat Jawa dan Madura saja, akan tetapi untuk seluruh umat Islam (keanggotaan SDI terbuka untuk semua lapisan masyarakat muslim).

Selanjutnya, menurut Fajar, (2021) pada tahun 1912 berkat keadaan politik dan sosial pada masa tersebut H.O.S. Cokroaminoto menggagas SDI untuk mengubah nama dan bermetamorfosis menjadi organisasi pergerakan yang hingga sekarang disebut Syarikat Islam (SI), Cokroaminoto mengubah yuridiksi SDI lebih luas yang dulunya hanya mencakupi permasalahan ekonomi dan sosial semata, ketika berganti nama menjadi SI, maka secara otomatis ruang lingkup semakin luas, bukan hanya permasalahan ekonomi dan sosial saja, akan tetapi melebar ke sudut lain, seperti kearah pendidikan, politik, agama, hukum, dan lain-lain, yang berguna untuk menyumbangkan semangat perjuangan islam dalam semangat juang rakyat terhadap kolonialisme dan imperialisme pada masa tersebut (Fajar, 2021).

Menurut Rugani, (2020) Cokroaminoto lahir di Desa Bakur, Madiun, Jawa Timur, pada tanggal 16 Agustus 1882, wafat pada tanggal 17 Desember 1934 M./ 10 Ramadhan 1353 H. dimakamkan Taman Makam Pahlawan (TMP) Pekuncen Daerah istimewa Yogyakarta. Berikut gambar Cokroaminoto:

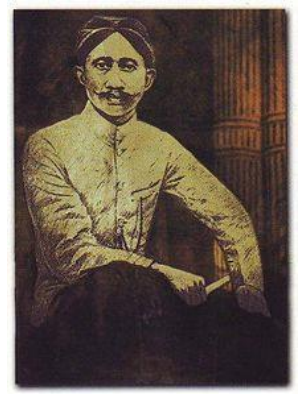

Gambar 1. Gambar lukisan Cokroaminoto

Cokroaminoto tidak pernah meletakan gelar raden di depan namanya. Cokroaminoto pula dibesarkan dalam tradisi keluarga priayi, Ia nasionalis dan sosialis yang menjunjung tinggi nilai-nilai Islam sekaligus (Wijaya, 2019). Para murid ternama seperti Ir. Soekarno, Musso, Kartosoewirjo yang 
memilih untuk berpisah jalan (berbeda ideologi), dan pertarungan mereka kemudian, amat mempengaruhi Perjalanan Republik Indonesia ini. Pemerintah kolonial Belanda kala itu, memberikan julukan kepada Cokroaminoto yaitu "Raja tanpa Mahkota".

Ketika kita berbicara Cokroaminoto maka tidak akan terpisan dengan sebuah organisasi dengan nama Syarikat Islam (SI), dikarenakan SI dibesarkan oleh Cokroaminoto, sehingga Cokroaminoto pun ikut besar dengan SI nya (Hutchinson, 2020). Menurut Mahardi, (2020) dalam perjalanannya Cokroaminoto dan SI tentunya manyak sekali lika-liku yang dirasakan, mulai dari kongres kedua yang diadakan di Surakarta pada tanggal 23 Maret 1913, terpilihlah H. Samanhudi sebagai ketua dan Cokroaminoto sebagai wakilnya. Dalam kongres ini menegaskan bahwa SI hanya terbuka bagi rakyat biasa (para pegawai pemerintah tidak boleh menjadi anggota). Bukti kepiawaian Cokroaminoto dalma berpolitik dibuktikan pada tanggal 18-20 April 1914 diadakan kongres SI yang ke III di Yogyakarta yang dihadiri oleh 80 perkumpulan SI Kota. Pada kongres inilah Cokroaminoto menyingkirkan H. Samanhudi dari kursi Ketua, dan Cokroaminoto didampingi oleh Goenawan sebagai wakil ketua. Sekitar 1 tahun selanjutnya (1915) merupakan awal mula pahampaham konumis mulai masuk ke ketubuh SI, dengan ditandai berdirinya Indische Sociaal Democratische Vereeniging (ISDV).

Selanjutnya, menurut Nugraha, (2018) pada tanggal 17-24 Juni 1916 juga, diadakan kongres SI yang keempat di Bandung. Dalam kongres ini SI sudah mulai melontarkan pernyataan politiknya, yaitu SI bercita-cita menyatukan seluruh penduduk Indonesia sebagai suatu bangsa yang berdaulat (merdeka). Selanjutnya, tahun 1917 SI (CSI) mengadakan kongres di Batavia (Jakarta). Dalam kongres ini CSI menegaskan ingin memperoleh pemerintahan sendiri (kemerdekaan). Dalam kongres ini juga CSI mendesak pemerintah Hindia Belanda agar membentuk Dewan Perwakilan Rakyat (volksraad). Maka SI mencalonkan Cokroaminoto dan Abdul Muis sebagai wakilnya di volksraad. Di tahun ini pula Semaoen (murid Sneevliet di ISDV) memimpin SI cabang Semarang. Disinilah mulai adanya infiltrasi dari kaum komunis dalam tubuh Syarikat Islam.

Jadi, dapat pemateri simpulkan bahwa perjalanan panjang Cokroaminoto bersama Syarikat Islam, tidak lah bisa sipisahkan, akan tetapi justru malah saling berkaitan dan saling melengkapi, adapun skema perjalanan hidup Cokroaminoto dan Syarikat Islam akan Pemateri sampaikan pada bagian pelaksanaan kegiatan pengabdian ini.

\section{B. PELAKSAAAN DAN METODE}

Metode kegiatan yang dilakukan dalam pengabdian kepada masyarakat ini, adalah berupa orasi ilmiah. Orasi ilmiah ini dengan sengaja dikalsanakan oleh panitia Pengenalan Akademik Kampus (PAK) Universitas Cokroaminoto Yogyakarta, yang bertujuan untuk memberikan pengetahuan dan pemahaman kepada mahasiswa baru. Kegiatan PAK ini, berupa kegiatan orasi ilmiah yang dilaksanakan secara virtual dalam bentuk webinar, yang dilakukan dengan menggunakan platform Zoom Meeting dengan metode deskriptif, yaitu pendekatan kualitatif dengan mengumpulkan data berupa narasi yang berwujud tulisan, gambar, audio, atau pun visual selama kegiatan webinar orasi ilmiah berlangsung serta melakukan tanya jawab atau bertukar pikiran secara terstruktur dengan peserta kegiatan.

Di kampus Universitas Cokroaminoto Yogyarta (UCY), seluruh kegiatan perkuliahan pada setiap program studi di UCY dan bahkan kegiatan kemahasiswaan yang mengundang banyak orang dilaksanakan secara daring melalui beberapa media online yang telah tersedia seperti, You Tube streaming, Google Meet, Zoom, dan Google Classroom serta platform lainnya. Dalam kegiatan orasi ilmiah ini pemateri menggunakan platform Zoom, karena lebih mudah dan lebih familiar pada semua kalangan, metode yang digunakan dalam orasi ilmiah tersebut adalah metode deskriptif dengan pendekatan kualitatif yaitu mengumpulkan data berupa narasi yang berwujud tulisan, gambar, audio atau pun visual selama kegiatan berlangsung.

\section{HASIL DAN PEMBAHASAN}

Dalam kegiatan webinar ini, yang menjadi peserta adalah Mahasiswa baru Universitas Cokroaminoto Yogyakarta tahun akademik 2021/ 2022, Kampus UCY beralamatkan di Jl. Perintis Kemerdekaan, Gambiran, Kelurahan Pandeyan, Kecamatan Umbulharjo, Kota Ygyakarta Kode Pos 55161. UCY memiliki 5 Fakultas yaitu: Fakultas Keguruan dan Ilmu Pendidikan, Fakultas Agama Islam, Fakultas Ekonomi, Fakultas Hukum dan Fakulas Teknik.

Kegiatan webinar ini dilaksanakan pada hari Selasa, 21 September 2021, mulai jam 08:00 sampai dengan jam 11:30 WIB, dengan dipandu oleh moderator dari panitia PAK. Saya sebagai pemateri (yang menyampaikan orasi ilmiah) ketika kegiatan berlangsung pemateri tidak langsung menyampaikan Sejarah dan Pemikiran Cokroaminoto, melainkan pemateri memberikan awalan/ pengantar diantaranya perbedaan antara Siswa dengan Mahasiswa, perbedaan cara belajar Siswa dengan Mahasiwa, perbenaan penilaian antara Siswa dan Mahasiswa dan lainnya. Pemateri juga menyampaikan tipe-tipe mahasiswa, paling tidak terrangkum menjadi 5 tipe mahasiswa, yaitu: 
1. Mahasiswa kupu-kupu (kuliah pulang-kuliah pulang), 2. Mahasiswa kunang-kunang (kuliah nangkring-kuliah nangkring), 3. Mahasiswa kurakura (kuliah rapat-kuliah rapat), 4. Mahasiswa kudakuda (kuliah dagang-kuliah dagang), 5. Mahasiswa kue-kue (kuliah gawe-kuliah gawe atau kerja). Hal tersebut dengan sengaja pemateri sampaikan, supaya para mahasiswa baru mengetahui jenis atau tipe-tipe mahasiswa, akan tetapi yang pemateri tekankan adalah menjadi mahasiswa kura-kura atau kuliah rapat-kuliah rapat, yang bermuara nantinya untuk menjadi aktivis kampus yang tetap mengetahui skala prioritas.

Materi dalam kegiatan webinar ini, sebetulnya bisa diakses melalui channel You Tube pemateri sendiri pada link: https://youtu.be/iohx_VANZlo selanjutnya, diawal penyampaian materi dimuali dengan pengenalan Cokroaminoto, apabila berbicara Cokroaminoto maka tidak akan terlepas dengan perjalanan biliau dengan Syarikat Islam. Seperti yang sudah pemateri sampaikan sebelumnya bahwa Cokroaminoto dan SI saling mengisi dan saling melengkapi, karena Cokroaminoto besar oleh SI dan sebaliknya SI dibesarkan pula oleh Cokroaminoto.

Berikut ini akan pemateri lampirkan skema perjalanan kehidupan Cokroaminoto dan skema perjalanan Syarikat Islam, pemateri dengan sengaja memberikan hal tersebut supaya mempermudah pembaca untuk memahaminya, teks berwarna merah adalah perjalanan kehidupan Cokroaminoto sdangkan teks yang hitam adalam perjalanan Syarikat Islam dari masa kemasa. Cokroaminoto adalah pahlawan nasional sekaligus pemimpin abadi Sarekat Islam (SI). Cokroaminoto memimpin SI sejak 1912 hingga wafat pada 17 Desember 1934, hari ini tepatnya 109 tahun silam, di bawah kendalinya Cokroaminoto SI sempat menjadi salah satu organisasi massa terbesar dalam sejarah pergerakan nasional dan Cokroaminoto juga merupakan guru bagi tokoh-tokoh yang kelak sangat berpengaruh, seperti Sukarno, Musso, hingga S. M. Kartosoewirjo. Maka, tidak berlebihan jika sosok Cokroaminoto disebut sebagai bapaknya bapak bangsa Indonesia (Guru Bangsa). Skema perjalanan hidup Cokroaminoto, pemateri sampaikan pada gambar berikut:

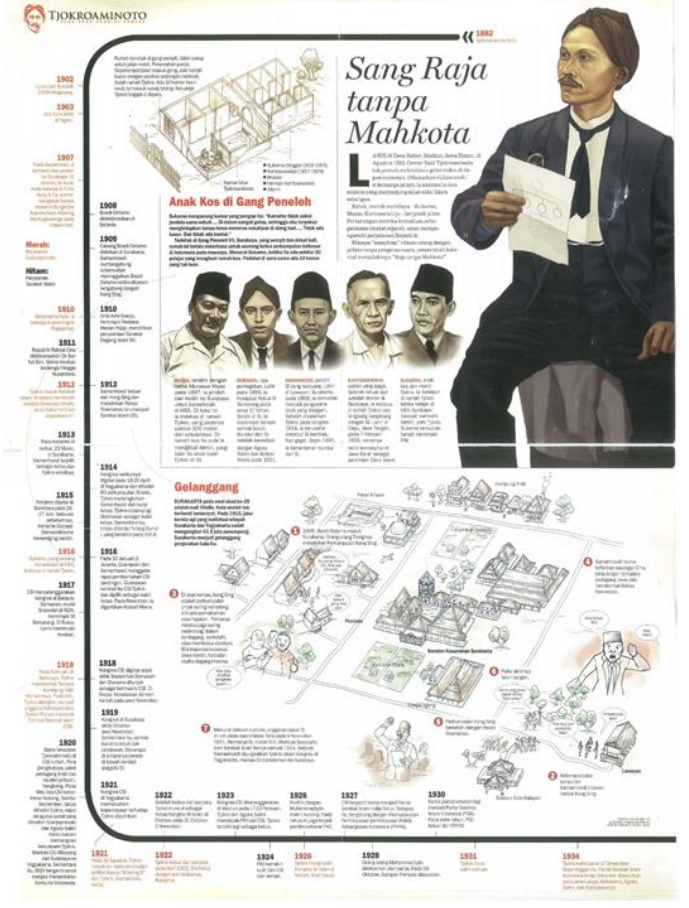

Gambar 2. Skema Perjalanan Hidup Cokroaminoto

Berikut, pemateri akan menyampaikan jejak langkah Cokroaminoto secara singkat, dimulai dari latar belaknag keluarganya yang termasuk keluarga ningrat atau darah biru, Cokroaminoto lahir di Desa Bakur, Kabupaten Madiun, Provinsi Jawa Timur, tepatnya pada tanggal 16 Agustus 1882. Cokroaminoto memiliki Ayah dengan nama R. M. Tjokroamiseno (Cokroaminseno), yang mana ayahnya adalah seorang wedana atau asisten Bupati kala itu. Sedangkan sang kakek, Bernama R. M. Adipati Tjokronegoro (Cokromegoro), dan pernah menjadi Bupati Ponorogo kala itu.

20 tahun selanjutnya tepatnya pada tahun 1902, Cokroaminoto merupakan calon PNS (Pegawai Negeri Sipil) istilah jaman sekarang, karena Cokroaminoto telah lulus dari Opleiding School voor Inlandsche Ambtenaren (OSVIA) di Magelang Jawa Tengah. OSVIA adalah sekolah bagi calon abdi negara pemerintah kolonial Hindia Belanda. Dan sesudah tamat dari OSVIA, Cokroaminoto sempat bekerja di kesatuan pegawai administratif di Ngawi. Pada tahun 1912 Cokroaminoto masuk kedalam organisasi yang bernama Syarikat Dagang Islam (SDI) dan Cokroaminoto juga menyarankan atau memebrikan gagasan supaya berganti nama menjadi Syarikat Islm (SI). Hal tersebut diamini oleh Haji Samanhudi dan bersepakat untuk mengubah yuridiksi dari SDI menjadi SI. Pada waktu itu Cokroaminoto sendiri adalah anggota SI Surabaya yang kemudian menjadi ketua cabang Surabaya. Pada tahun 1913 Cokroaminoto menjadi wakil ketua Central Sarekat Islam (CSI) dalam kongres SI pertama pada 25 Maret 1913 di Surakarta, Cokroaminoto ditunjuk menjadi wakil 
ketua CSI mendampingi Haji Samanhudi sebagai ketua CSI yang berpusat di Solo. Di tahun 1914 Cokroaminoto terpilih sebagai ketua CSI dalam kongres kedua pada 19-20 April 1914 di Yogyakarta dan berhasil mengalahkan Samanhudi yang sebagai ketua sebelumnya. Dan selanjutnya Kantor pusat SI pun dipindahkan yang awalnya dari Surakarta dipindah ke Surabaya. Di tahun pertama kepemimpinan Cokroaminoto, sejarah mencatat ada sekitar 400.000 orang anggota resmi SI kala itu.

Pada tahun 1918, ada sebuah kegiatan yang diberi nama Aksi Bela Islam pada awal Februari 1918, dimana Cokroaminoto memimpin Tentara Kandjeng Nabi Mohammad (TKNM) di Surabaya dan menggerakkan aksi bela Islam sebagai respon atas tulisan di majalah Djawi Hiswara yang dianggap menghina Nabi Muhammad. Tahun itu, massa SI berjumlah 450 ribu orang. Dan pada tahun 1919, sebagai dampak aksi tersebut, anggota SI membengkak menjadi 2,5 juta orang. Selajutnya di tahun 1923 Partai Sarekat Islam (PSI) setelah berhasil mendepak anggota SI yang terindikasi berafiliasi dengan paham kiri, akhirnya Cokroaminoto mengubah nama dari SI menjadi Partai Sarekat Islam (PSI) yang jelas-jelas berhaluan politik. Di tahun 1929 dalam kongres yang digelar pada Januari 1929, diputuskan bahwa PSI berganti nama lagi menjadi Partai Sarekat Islam Indonesia (PSII). Cokroaminoto kembali terpilih sebagai ketua umum untuk kesekian kalinya.

Dan akhirnya, pada tahun 1934 Tjokroaminoto wafat, tepatnya pada tanggal 17 Desember 1934. Dan setelah itu, PSII terpecah-belah dengan hengkangnya beberapa tokoh penting, termasuk Haji Agus Salim setelah berselisih dengan adik Cokroaminoto, yaitu Abikusno Cokrosuyoso. Pada tahun 1961 Cokroaminoto mendapatkan gelar sebagai Pahlawan Nasional, maka sudah berang tentu kita mengetahui kalua Cokroaminoto memang tidak sempat menikmati alam kemerdekaan. Namun, pengaruh dan sumbangsihnya bagi gagasan bangsa Indonesia untuk berdiri di atas kaki sendiri sangat besar. Bahkan Presiden Sukarno atas nama pemerintah Republik Indonesia menetapkan H.O.S. Cokroaminoto sebagai pahlawan nasional pada 1961.

Di atas sudah pemateri paparkan secara sepintas, terkait perjalanan kehidupan Cokroamino, selanjutnya pemateri memaparkan pemikiran Cokroaminoto. Beliau adalah bapak kebangsaan, sang guru bangsa, raja tanpa mahkota dan lain sebagainya, julukan yang diterima atau julukan yang diberikan kepada Cokroaminoto. Sebelum melanjutnya kepada pemikiran Cokroaminoto berikut pemateri sampaikan gambar ketika kegiatan webinar berlangsung:

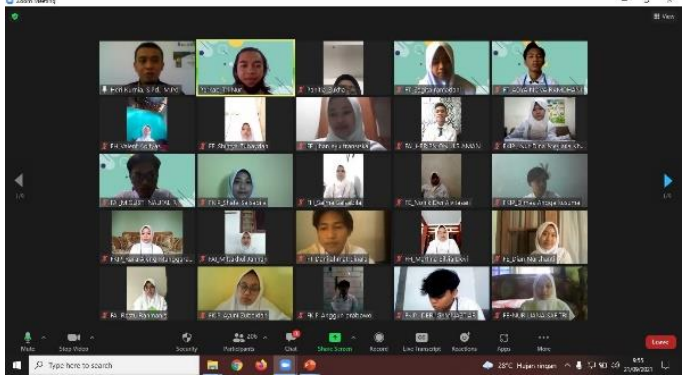

Gambar 3. Kegiatan Webinar Berlangsung

Apabila kita ingin mengetahui pemikiran Cokroaminoto, maka tidak bisa dipisahkan dengan murid-murid Cokroaminoto yang melegenda dan pernah mewarnai perjalanan bangsa ini, yaitu Sukarno, Musso dan Kartosuyiryo, seperti pada gambar dibawah ini:

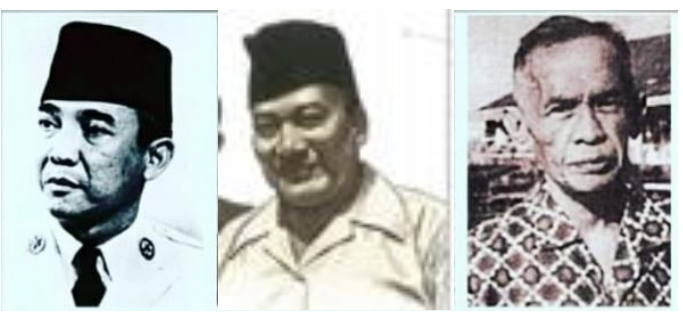

Gambar 4. Tiga Murid Cokroaminoto Yang Terkenal

Pada gambar 4 di atas, dari gambar paling kiri ke kanan, adalah Sukarno, Musso dan kartosuwiryo. Ke-3 murid tersebut, sangatlah berpengaruh terhadap berjalanan kehidupan bangsa Indonesia, baik sebelum kemerdekaan maupun pasca kemerdekaan Indonesia.

Seperti yang sudah kita ketahui bersama, bahwa sosok Sukarno merupakan bapak proklamator dan sekaligus presiden Indonesia yang pertama, yang memiliki haluan nasionalis dan juga penggagas dasar negara kita Indonesia, yaitu Pancasila. Sejarah mencatat, bahwa Sukarno pernah menimba ilmu dari Cokroaminoto, buktinya Sukarno pernah tinggal di rumah Cokroaminoto ketika sekolah di Hoogere Burgerschool dalam ejaan bahasa Belanda lebih baru Hogere Burgerschool disingkat HBS merupakan pendidikan menengah umum pada zaman Hindia Belanda untuk orang Belanda, Eropa, Tionghoa, dan elit pribumi dengan bahasa pengantar bahasa Belanda. Selanjutnya menurut Ridwan, (2020) bahkan sosok Sukarno pernah bergabung dengan Syarikat Islam, meskipun pada akhirnya dikeluarkan dari Syarikat Islam, karena Sukarno terlalu nasionalis (terlalu menonjolkan dan terlalu mencolok sikap nasionalismenya), jadi Sukarno adalah murid Cokroaminoto yang berhaluan nasionalis. Bukti Sukarno mewarnai pergerakan Indonesia, bawa Sukarno berhasil 
memproklamasikan kemerdekaan Indonesia pada 17 Agustus 1945.

Selanjutnya, gambar yang tengah pada gambar ke-4 di atas, tokoh komunis dengan nama Musso, apabila kita mendengar nama Musso maka tentunya tidak biasa dipisahkan dengan tokoh yang berhaluan kiri lainnya seperti: Semaun, Darsono, H. Misbah, dan tokoh komunis lainnya. Awal mula masuknya komunis ke Indonesia ditanda dengan datangnya seorang tokoh sosialis yang berasal dari Belanda dengan nama Hendricus Josephus Franciscus Marie Sneevliet atau lebih dikenal sebagai Henk Sneevliet atau dengan nom de guerre sebagai nama samaran dalam perjuangannya. Sejarah mencatat, bahwa Musso, lebih spesifiknya seperti Semaun dan Darsono yang mana keduanya pernah bergabung dengan SI dan bahkan pernah menduduki posisi strategis dalam Syarikat Islam. Mereka (yang berhaluan kiri) tentunya masuk ke tubuh SI dengan cara melakukan infiltrasi, dimana yang menjadi wadah organisasinya adalah SI, sedangkan pergerakan yang dilakukannya disisipi ideologi komunis. Namun, setelah diketahui bahwasanya mereka melakukan infiltrasi maka dikeluarkan mereka dari Syarikat Islam. Sama halnya seperti Sukarno, bahwasanya Musso juga pernah menimba ilmu dari Cokroaminoto, dan lebih tepatnya Musso adalah murid Cokroaminoto. Bukti Musso (komunis) pernah mewarnai perjalanan bangsa Indonesia, adalah ketika mereka melakukan pemberontakan-pemberontakan dari mulai pemberontakan di Madiun, di bumi Pasundan sampai menemukan titik puncaknya (klimaknya) pada tahun 1965 yaitu peristiwa G30S/PKI, yang sekarang sudah dilarang adanya komunis di negara kita, dengan bentuk dan dengan sarana apapun.

Gambar yang paling kanan adalah tokoh dengan nama Sekarmaji Marijan (S.M.) Kartosuwiryo, merupakan tokoh pergerakan dalam agama (yakni agama Islam). Namanya sangat termashur di Jawa Barat (di bumi Parahyangan). Sama seperti Sukarno dan Musso, bahwasanya Kartosuwiryo juga pernah menimba ilmu dan belajar dari Cokroaminoto, sebagai bukti bahwasanya Kartosuwiryo adalah murid Cokroaminoto, sejarah mencatat bahwasanya Kartosuwiryo ikut bergabung dengan organisasi Syarikat Islam dan ketika itu yang menjadi ketua Syarikat Islam adalah Cokroaminoto. Kartosuwiryo dikenal sebagai tokoh dari lahirnya Darul Islam Tentara Islam Indonesia (DI-TII), bukti kalau Kartosuwiryo pernah mewarnai perjalanan hidup bangsa Indonesia, adalah dengan melakukan deklarasi atau memproklamirkan Negara Islam Indonesia (NII).

Dari paparan di atas, maka pemateri mengambil kesimpulan bahwa 3 tokoh ternama di atas adalah murid Cokroaminoto. Selanjutnya, makan bisa pemateri tarik benang merah bahwa gaya berpikir atau pemikiran Cokroaminoto dalam mendidik dan mengarahkan para muridnya, yakni Cokroaminoto tidak pernah memaksakan atau mengharuskan muridnya untuk memilih sebuah ideologi, atau Cokroaminoto memilihkan salah satu ideologi, melainkan dari ketiga muridnyalah yang sudah menentukan ideologinya masing-masing. Maka, dalam hal ini Cokroaminoto mengarahkan dari masing-masing muridnya yang sudah memilih dan mementukan ideologinya masing-masing. Maka dari itu, konsep pendidikan di negara kita Indonesia, seharusnya demikian, yaitu tidak boleh memaksakan peserta didik untuk menjadi seperti yang diinginkan oleh pendidik, melainkan mengarahkan peserta didik berdasarkan keinginan dan kemauannya serta kemampuan dari masingmaisng, tentunya apabila salah drai peserta didik maka dirahkan supaya benar.

\section{PENUTUP}

\section{Simpulan}

Cokroaminoto menyandang gelar Sang Guru Bangsa, Raja tanpa Mahkota dan lain sebagainya karena beliau memiliki 3 murid utama yaitu Sukarno, Musso dan Kartosuwiryo yang memiliki ideologi berbeda-beda (nasionalis, komunis dan agamis). Dari ketiga murid ternama Cokroaminoto, ke-3 nya pun mampu mewarnai perjalanan Negara Republik Indonesia ini terlebih lagi pada masa orde lama yang tercantum dalam istilah NASAKOM (Nasionalis, Agamis dan Komunis). Maka bisa ditarik kesimpulan, bahwa pemikiran Cokroaminoto dalam membesarkan ketiga muridnya, bukan untuk dipaksa memilih sebuah ideologi, melainkan mengasah dan mempertajam dari ideologi yang sudah dipilihnya masing-masing.

\section{Saran}

Sebagai generasi muda yang berkualitas, maka jangan pernah melupakan sejarah, terebih lagi sejarah tokoh ternama seperti H.O.S. Cokroaminoto sebagai guru bangsa, yang memiliki 3 poin penting (trilogi) yaitu: 1. Sebersih-bersih tauhid, 2. Setinggitinggi ilmu, dan 3. Sepandai-pandai siasah.

\section{E. DAFTAR PUSTAKA}

Ahdar, A., Musyarif, M., \& Rahman, A. R. A. (2021). Pemikiran Pendidikan Politik HOS Tjokroaminoto. Foramadiahi. http://journal.iainternate.ac.id/index.php/foramadiahi/article/vie w/305

Bone, H. I. I., \& Cokroaminoto, J. H. (n.d.). Metodologi Pemikiran Hukum Islam Fazlur Rahman. In jurnal.iain-bone.ac.id. https://www.jurnal.iain-

bone.ac.id/index.php/albayyinah/article/down $\operatorname{load} / 322 / 309$

Brumfiel, C. M., Jefferson, I. S., Wu, A. G., Strunck, 
J. L., \& ... (2021). A national webinar for dermatology applicants during the COVID-19 pandemic. Journal of the American .... https://www.jaad.org/article/S01909622(20)32633-5/abstract

Compen, B., Witte, K. De, \& ... (2021). The impact of teacher engagement in an interactive webinar series on the effectiveness of financial literacy education. British Journal of .... https://doi.org/10.1111/bjet.13013

Fajar, A. (2021a). MENUAI KUASA ATAS ISU AGAMA: POLITISASI HOS COKROAMINOTO TERHADAP POLEMIK PENISTAAN AGAMA PADA SURAT KABAR DJAWI HISWORO DI N.. erepository.perpus.iainsalatiga.ac .... http://erepository.perpus.iainsalatiga.ac.id/id/eprint/1 0473

Fajar, A. (2021b). MENUAI KUASA ATAS ISU AGAMA: POLITISASI HOS COKROAMINOTO TERHADAP POLEMIK PENISTAAN AGAMA PADA SURAT KABAR DJAWI HISWORO DI ... $\quad$ erepository.perpus.iainsalatiga.ac .... http://erepository.perpus.iainsalatiga.ac.id/id/eprint/1 0473

Fajar, A. (2021c). Politisasi Isu Agama di Media Massa: Strategi Politik Hos Cokroaminoto dalam Surat Kabar Djawi Hisworo (1918). Journal of Islamic History. https://journal.nurscienceinstitute.id/index.ph $\mathrm{p} / \mathrm{jih} /$ article/view/115

Gegenfurtner, A., Zitt, A., \& Ebner, C. (2020). Evaluating webinar-based training: a mixed methods study of trainee reactions toward digital web conferencing. International Journal https://doi.org/10.1111/ijtd.12167

Hennus, M. P., \& Dam, M. van. (2021). Presenting a webinar-the need for a standard operating procedure? In Medical teacher. Taylor \& Francis.

https://doi.org/10.1080/0142159X.2020.1752 366

Hutchinson, J. W. (2020). EML Webinar overview: new developments in shell stability. Extreme Mechanics Letters. https://www.sciencedirect.com/science/article /pii/S235243162030119X

Mahardi, D. P. (2020). Pemikiran Ekonomi Sosialis Haji Oemar Said Cokroaminoto. etheses.iainponorogo.ac.id. http://etheses.iainponorogo.ac.id/12747/

Nugraha, J. N. (2018). Analisis pemikiran politik dan hukum menurut pandangan islamis Haji Agus Salim. repository.um.ac.id. http://repository.um.ac.id/id/eprint/52271

Ridwan, E. H. (2020). Perspektif Hos Tjokroaminoto Tentang Pendidikan Islam. Paedagogie: Jurnal Pendidikan Dan Studi .... http://ejurnal.staimuttaqien.ac.id/index.php/paedagog ie/article/view/28

Rugani, J. (2020). Konsep Pemikiran Pendidikan Kebangsaan Haji Oemar Said Cokroaminoto Dalam Perspektif Pendidikan Islam, Penerbit. In Tohar Media, Makassar.

Wijaya, D. R. P. (2019). Kontribusi wanita Syarikat Islam Indonesia cabang Banjarnegara dalam bidang pendidikan, sosial ekonomi, dan keagamaan tahun 2010-2016. digilib.uinsgd.ac.id.

http://digilib.uinsgd.ac.id/26091/ 